\title{
The Changing Role of the State in Liberal Market Economies
}

\section{Citation}

Peter Hall. 2015. "The Changing Role of the State in Liberal Market Economies." In The Oxford Handbook of Transformations of the State, 426-444. Oxford: Oxford University Press.

\section{Published Version}

https://global.oup.com/academic/product/the-oxford-handbook-of-transformations-of-thestate-9780199691586?cc=us\&lang=en\&\#

\section{Permanent link}

http://nrs.harvard.edu/urn-3:HUL.InstRepos:34298849

\section{Terms of Use}

This article was downloaded from Harvard University's DASH repository, and is made available under the terms and conditions applicable to Open Access Policy Articles, as set forth at http:// nrs.harvard.edu/urn-3:HUL.InstRepos:dash.current.terms-of-use\#OAP

\section{Share Your Story}

The Harvard community has made this article openly available.

Please share how this access benefits you. Submit a story.

Accessibility 


\title{
The Changing Role of the State in Liberal Market Economies
}

\author{
Peter A. Hall \\ Minda de Gunzburg Center for European Studies, \\ Harvard University \\ 27 Kirkland Street \\ Cambridge MA 02138 \\ phall@fas.harvard.edu
}

November 2012

Chapter 23 of The Oxford Handbook of Transformations of the State, edited by StephanLeibfried,Frank Nullmeier, Evelyne Huber, Matthew Lange, Jonah Levy, and John D. Stephens (NY: Oxford University Press forthcoming) 
This chapter is about the role of the state in the economy and how it has changed over the past seven decades in the liberal market economies of the developed world, which are marked by high levels of market competition. In this volume, these are called 'liberal states' of the sort found in Britain, Canada, the United States and Ireland, the cases considered here. Although the timing of shifts in the role of the state varies across countries, the focus of this analysis is on changes and continuities across two broad periods, a Keynesian era, running from the Second World War to the end of the 1970s, often described as a golden age of high rates of economic growth, and a subsequent neo-liberal era, marked by slower rates of growth and efforts to increase the role of markets vis-à-vis states in the allocation of resources.

\section{Images of the Liberal State}

Images of the liberal state have been deeply influenced by three waves of literature in comparative political economy. Each emphasizes a distinctive set of differences that reflects the economic preoccupations of its time. Inspired by Shonfield's (1969) magisterial overview, the literature of the first wave focused on cross-national variation in the character of state intervention into the economy, emphasizing the extent to which public officials could exert direct control over the allocation of resources among economic endeavors. Thus, Shonfield contrasted the interventionist character of economic planning in France, active labor market policy in Sweden, and Germany's ordo-liberal economic order. Zysman (1983) stressed the influence of states over flows of funds in the financial system, while Johnson (1982) highlighted the formal and informal relationships between business and developmental states (cf. Evans 1995). In this context, the efforts of successive British governments to promote national economic planning seemed anemic (Leruez 1975; cf. McArthur and Scott 1966). 
This literature was preoccupied with the attempts of governments to modernize their industrial base to compete more effectively in the world economy - an optic appropriate for the 1950s and 1960s when the shadow of high inter-war unemployment hung over the world and declining barriers to trade brought stiff competition from American multinationals. On this plane, the striking feature of policy in liberal states was its emphasis on 'arm's length' economic management of the sort advocated by John Maynard Keynes, whose doctrines suggested that governments could ensure full employment, without extensive intervention, by manipulating interest rates and the budget balance to moderate fluctuations in economic activity (Hall 1989; Hansen 1968). Many policy-makers in liberal states were skeptical about the value of economic planning or active industrial policy; and analysts judged their modest efforts in that direction ineffective, partly because these states lacked tools, offering control over flows of funds in the financial system that might have given them more influence over the investment decisions of firms (Zysman 1983; Leruez 1975; Blank 1978).

By the middle of the 1970s, popular anxiety in the developed democracies shifted away from economic modernization toward rates of inflation and unemployment rising in tandem after the collapse of the Bretton Woods monetary system and commodity price shocks. Analysts began to focus on the problem of how governments could reduce inflation without increasing unemployment, and the result was a literature on neo-corporatism reviewed in this book by Huo and Stephens (Hibbs 1977; Goldthorpe 1984). The literature on neo-corporatism focused on the organization of trade unions and employers on the premise that, where wage bargaining could be coordinated by associations encompassing enough to promote the economy-wide interests of firms and workers and influential enough to enforce wage agreements, the rate of inflation could be lowered without extravagant increases in unemployment. In such settings, the role of the state 
was to promote encompassing producer groups, guarantee that concessions made by workers would flow into investment rather than dividends, and provide a macroeconomic stimulus or social benefits in return for wage concessions (Przeworski and Wallerstein 1982). Many scholars thought neo-corporatist states had distinctive styles of policy-making based on a search for consensus among social partners and the devolution of authority over policy onto producer groups (Katzenstein 1984; Schmitter and Lehmbruch 1978).

From this perspective, liberal states were again the foil, although notable differences among them became salient. In the modal cases, best represented by the U.S., U.K. and Canada, governments displayed little interest in economy-wide wage coordination or bolstering the capacities of trade unions and employers to coordinate skill formation (Thelen 2004). Although they occasionally implemented incomes policies designed to reduce rates of inflation, such as the 1974 Social Contract in Britain and the incomes policy of the Nixon administration in the U.S., those agreements were typically forced on reluctant employers or unions and short-lived (Regini 1984). Australia and Ireland were the limiting cases. Australia mounted a durable incomes policy during the 1970s and 1980s, while Ireland secured economy-wide wage coordination for twenty years after 1987. Even in these countries, however, governments negotiated only a limited range of policies with business and labor and did little to coordinate vocational training (Hardiman 1988). Their agreements often resembled 'social pacts' rather than the deeper cooperation of neo-corporatist countries (Avgadic et al. 2011).

Once inflation had been brought under control during the 1980s, the attention of political economists turned toward the challenges of globalization, which inspired a wave of literature commonly associated with ‘varieties of capitalism’ (Kitschelt et al. 1999; Hall and Soskice 2001; Amable 2003). These analyses distinguish between 'coordinated market economies', which 
include many neo-corporatist cases, and 'liberal market economies', encompassing the countries examined here. In contrast to the first wave, however, the distinctions now drawn between political economies turn, not on the character of state intervention in the economy, but on the ways in which firms coordinate their endeavors. In liberal market economies, firms rely primarily on competitive markets to secure access to finance, skills, labor and technology, while firms in coordinated market economies rely more heavily on collaborative arrangements, often coordinated by business associations or trade unions.

The implications about the role of the state in the economy are correspondingly nuanced. Broadly speaking, this literature assumes that governments will be responsive, not only to electoral pressure, but to pressure from business interests and labor organizations, often seeking to preserve the competitive advantages of their sectors. Since companies operating in liberal market economies draw many advantages from their capacities to redeploy resources readily, they often press governments to make markets for inputs more flexible, and liberal states have been responsive to such pressures. Thus, this perspective does not rule out episodes of forceful state intervention, especially to make labor markets more competitive, as the anti-union efforts of the Thatcher and Reagan governments did, or to cope with a financial crisis, as in the bail-out programs of the U.S. and U.K. in 2008-09 (Gamble 1994; cf. Levy 2006). As Polanyi (1944) noted years ago, making markets more competitive often requires forceful initiatives from the state. 


\section{Liberal States in the Keynesian Era}

The actions taken by governments in the liberal market economies during the Keynesian era correspond well to these portraits of the liberal state. Britain and the United States will be treated here as paradigmatic cases and Ireland and Canada discussed more briefly.

After the Second World War, the British and American governments feared mass unemployment, as millions of soldiers were demobilized, a phenomenon the British associated with the intense class conflict of the 1920s and 1930s. Thus, effective governance seemed to require finding the basis for a compromise between the owners of capital or middle class managers and members of a working class whose grim living conditions were sources of real grievance. In the U.S., where an ideology of equal opportunity undercut class-based political appeals, the analogous challenge was how to sustain stability in a country marked by prominent racial divisions and two separate social orders, built on segregation in the South and uneasy integration in the North. In Canada, economic issues were cross-cut by sub-national tensions in a federal system (Jenson 1989).

In 1945, the British elected a Labour Government whose response to these problems was highly interventionist. Important firms were nationalized, including the Bank of England and much of the coal, steel and transport industries, bringing more than 20 percent of industry under government control. The government experimented with binding wage and price guidelines during the 1940s and rationed many goods until the late 1950s. Physicians were forced into a National Health Service and universal pension and unemployment schemes expanded (Beer 1969). Like the steps taken to build welfare states in Canada, these moves indicated that even liberal states can sometimes be interventionist. 
Parallel moves in the U. S, were more muted but consequential. The GI Bill made university education affordable for a generation of veterans, and the 1956 initiative to build an inter-state highway system was a $\$ 425$ billion investment in jobs and infrastructure. The decision to fight a Cold War sparked decades of investment in military technology with civilian spin-offs, in effect, a massive industrial policy oriented to research and development. The space program of the 1950s was its natural concomitant. In such respects, liberal states are far from night-watchmen states. In both Britain and the U.S., the two decades after the Second World War were marked by considerable public enthusiasm for a modernizing state and major expansions in public expenditure and policy-making that left lasting marks on liberal regimes.

However, this interventionist impulse always faced opposition from the political right and did not survive the 1970s. By the end of the 1950s, President Dwight Eisenhower was warning of the dangers of a 'military-industrial' complex, and politicians on both sides of the British political spectrum had accepted a Keynesian compromise, dictating that unemployment was to be addressed, not by further nationalizations, but with activist macroeconomic policy that used the budget balance and quantitative controls on credit to moderate the fluctuations of the business cycle. Competition was strengthened via the abolition of resale price maintenance, and the efforts of a Conservative government to construct a national economic plan foundered on the government's unwillingness to force it upon a fragmented business community (Blank 1978; Leruez 1975).

In Britain, the high-water mark for state intervention came with the 1964 electoral victory of a Labour Party under Harold Wilson that promised 'to reforge Britain in the white, hot heat of the scientific revolution'. Its initiatives lent a more interventionist cast to the Keynesianism of the period, with the creation of a Department of Economic Affairs and an Industrial 
Reconstruction Corporation aimed at restructuring industries; but a 1967 effort to rationalize wage bargaining failed and the orientation of macroeconomic policy-making soon shifted away from growth toward a succession of efforts to stave off recurrent balance of payments crises, culminating in IMF intervention in 1976 (Pemberton 2004).

In the United States, the Kennedy administration made Keynesian doctrine an official part of policy but did not attempt a national industrial policy beyond the sphere of defense. As tariff barriers fell, both economies became more open, but the volume of American trade remained a relatively small proportion of GDP, while Britain became a small open economy whose leaders continued to act as if they led a large, closed economy - making repeated attempts to defend the sterling exchange rate at the cost of turning macroeconomic policy into an ineffective 'stop-go' instrument (Brittan 1970). British policy was influenced by the prominent role that financial services centered in the City of London played in the economy, as an important source of international income, and as an influential source of support for the Conservative party. The financial sector associated with Wall Street played similar roles in the United States, reinforced by the growing importance of the dollar vis-à-vis sterling as a global reserve currency.

Neither country developed the kind of export-led growth strategies being devised in Germany and Japan during these years, which exploited their institutional capacities for wage coordination to hold down unit labor costs, while depressing the exchange rate in order to promote exports (Kreile 1978; Johnson 1982; Martin 1979). Instead, the British and American approach was to promote growth led by domestic demand, based on efforts to liberalize domestic credit markets to support consumption and counter-cyclical macroeconomic policy designed to 
sustain the predictable growth in demand that underpins investment in mass manufacturing (Surrey 1982; Trumbull 2012).

In many respects, the Irish and Canadian cases paralleled those of their larger neighbors, even though both were smaller, more open economies. Irish policy was largely directed, from the 1960s, at attracting foreign direct investment via low corporate tax rates and an industrial development agency charged with bringing in foreign investment. As in Canada, the government relied on macroeconomic management rather than wage coordination or active industrial intervention to sustain economic growth (O’Connell and Whelan 2000).

Although a Liberal administration under Pierre Trudeau tried a more assertive industrial policy, in the form of a national energy program in 1980-84, for the most part, the Canadian state has been no more interventionist than its American counterpart (Clement and Williams 1989; Howlett et al. 1999) However, Canada developed a more extensive welfare state during the 1960s and 1970s, pushed by by social democratic political parties with close ties to organized labor often in coalition with farmers, and then adopted by other governing parties. By the 1970s, the result was a welfare state based on 'social liberalism' whose universalism bore comparison to its Nordic counterparts (Myles 1998). The enthusiasm of the American Democratic Party for similar measures was undercut by the tendency of many within its electoral coalition, especially from the South, to associate redistribution with aid for African-Americans (Steensland 2006; Alesina and Glaeser 2004).

\section{Liberal States in the Neo-Liberal Era}

The 1980s saw the beginning of a neo-liberal era during which the role of the state shifted. In large measures, these changes were precipitated by rising rates of inflation and declining rates of 
economic growth in the 1970s (cf. Ferguson et al. 2010). Lower rates of growth limited the scope for further expansion of the welfare state; and persistent stagflation gave rise to disillusionment with the Keynesian policies that had failed to restore prosperity in the 1970s, setting in motion a search for alternative routes to growth. The reaction was especially strong in Britain and the U.S. where governments had resorted to mandatory incomes policies to hold down inflation in the face of intense protests. Thus, an economic crisis became a legitimacy crisis, calling into question the authority of the state (Crozier et al. 1974; Sandbrook 2010). As more people became skeptical about the capacity of the state to manage the economy, they began to look more favorably on the view that growth was likely to be restored only if the role of the state in the economy was reduced (Blyth 2002; Prasad 2006).

The political reflection of this discontent was the electoral victory of the British Conservative Party under Margaret Thatcher in 1979 and of the Republican Ronald Reagan in 1980. As Krieger (1986) notes, amidst the economic turmoil of the 1970s, both leaders exploited a sense that once-great imperial powers could recover their glory only if markets were unfettered once again. At the same time, the development of monetarist economic doctrine and then rational-expectations economics offered a basis for skepticism about the effectiveness of government, lending credence to political platforms whose ulterior motivation was to bring about an irreversible shift in power from organized labor to capital (Cuthbertson 1979; Crystal 1979; Hall 1993). Thatcher and Reagan accomplished that task and provided templates for marketoriented policies across the world, not least in the European Union where the Single European Act of 1986 prescribed market competition as an antidote to Eurosclerosis, turning the European Commission into an agent for market liberalization (Glyn 2006; Jabko 2006; Hall and Lamont 2013). 
The initial watchwords of this neo-liberal program (labeled 'neo-conservative' by Americans) were privatization and deregulation. In the early 1980s, national enterprises were gradually sold off in Britain. The rationale was that private owners could operate them more efficiently, but these programs were also attractive because they offered windfall revenues to governments and the prospect of dramatically weakening the public sector trade unions. If over 7 percent of the British workforce worked in state-owned enterprises in 1980, less than 2 percent did by 1995, as more than $£ 50$ billion of state assets were sold off. Britain led on privatization, but the United States led on deregulation, with early initiatives in air transport and telecommunications. As Vogel (1998) observes, deregulation was really 'reregulation' but of a sort that intensifies competition in markets. In many cases, the privatized industries were utilities providing water, energy and communications that had once been seen as 'public services'.

The result was sometimes better service at lower prices, if mainly for customers located in large markets, but these results were by no means universal and the broader effect was to undercut older view of the state as responsible for the provision of public services. This neoliberal program had a major impact on the operation of states. On the premise that private providers are more efficient, governments began to contract out many of services public employees had once supplied, including trash collection, municipal transport, and even the operation of prisons. Of course, these steps also reduced the power of public sector unions and the number of secure jobs available to the manual working class.

Less visible are the steps taken by liberal states to introduce market discipline into the process of public policy-making itself, usually under the heading of the 'new public management.' These reforms went farthest in Britain, where the Thatcher Government was 
again the pioneer with an initiative labeled 'Next Steps', soon copied to some extent in New Zealand, Australia and Canada (Rhodes 1994). Behind these reforms is a profound changes in the conception of what good governance entails (Miller and Rose 1990; Moran 2003). This neoliberal vision sees citizens as consumers, owed the kind of consideration an attentive firm devotes to its customers, and government as an institution whose prime objective should be efficiency. From this perspective, civil servants were, not the guardians of a public interest, but employees whose units should compete with one another to ensure maximum efficiency while their responsiveness to the 'customers' is closely monitored. This is government run on market principles.

These reforms often separated the formulation of policy from its implementation, entrusting the latter to quasi-independent agencies monitored with new performance technologies. Resources were often allocated across departments on the basis of business plans constructed much as they might be by firms seeking funds from venture capitalists (Davies 2011). Within Britain's National Health Service, for example, regional health authorities competed with each other over the effective delivery of health services, and hospitals and trusts of general practitioners were asked to compete with one another for public resources allocated on the basis of cost effectiveness. Efforts were made to compute the value in equivalent income value of the use citizens made of libraries, sports clubs and art museums.

It is difficult to assess the overall effects of these reforms. In some cases, they reduced the cost of providing government services, although often with some corresponding loss in quality. The effects on popular conceptions of governance are less tangible but in the long run likely even more consequential. This neo-liberal vision of governance marks a departure from traditional images that saw public service as a vocation, rather than just another occupation, and 
the higher civil service as a body motivated by a distinctive culture based on collective ideals rather than market principles (Dyson 1980). In much the same way, the contention that some services are so basic to collective well-being that they should be distributed by 'public utilities' gave way to the neo-liberal view that all services are the same and best delivered by units dedicated to market-oriented principles of efficiency.

Of course, these traditional views were idealized images that often masked underlying deficiencies; but this shift in gestalt has long-term implications for the authority of the state. As visions shift toward that ones that see the state simply as another of many actors vying to provide citizens with services efficiently, the claims of the state on the resources of the public become more tenuous and electorates may become less willing to fund it (cf. Beer 1974). As trust in the state declines in both Britain and the U.S., this shift in perspective appears to be the greatest victory for neo-liberalism, albeit one that may limit the capacity of contemporary states to make the investments in education, research and industry on which the long-term prosperity of these countries depends.

By the 1990s, however, this type of discourse was hegemonic. Market-oriented policies were adopted by governments of all political hues, not only as faits accomplis, but as desirable reforms (Iversen 2006). The 'Third Way' espoused by the British Labour party under Tony Blair, to distinguish it from the preceding Thatcher government, contained only vague calls for a 'market economy' without a 'market society'. In practice, Labour strengthened the social safety net under the most vulnerable segments of the populace, such as single mothers and those on low incomes, without much altering the role of the state in the economy. 
In the realm of social policy, the most striking development in both Britain and the U.S. was a move to make the receipt of social benefits contingent on participation in the workforce. Bill Clinton turned 'welfare' into 'workfare' and expanded tax credits on earned income, and the Blair government followed with its 'Fair Deal'. The aspiration was to avoid the formation of a permanent underclass with no connections to the labor market, but the policies relied more heavily on sticks than carrots, and their insistence that work is the only route to respectability was reminiscent of Britain’s 1834 Poor Law enacted in a previous period when market principles were elevated to the status of public ideals. Indeed, some analysts have argued that, in combination with rising rates of incarceration in the U.S., these policies reflect new efforts on the part of such states to discipline the lower classes (Lacquant 2009; cf. Campbell 2010a).

As Huo and Stephens (in this volume) indicate, the governments of many corporatist political economies also began to make social benefits contingent on labor force participation, but they also provided training schemes and subsidized positions for the unemployed. By contrast, the active labor market policies of the liberal states remained minimal (see Table 22.1). To foster employment, they tended to rely on large, low-wage service sectors and meager unemployment benefits that forced people into such jobs (Esping-Andersen 1990). As the skills of their workforce began to lag behind those of their competitors and manufacturing jobs flowed overseas, however, liberal governments began to worry about improving the quality of education, focusing on the general skills dominant in these kinds of political economies (Iversen and Stephens 2007). The instruments applied to this problem reflected the dominant principles of neo-liberal governance, emphasizing new metrics for judging the performance of schools and students, penalties for schools that did badly on standardized tests, and the establishment of more 
competitive markets in education via the establishment of charter schools in the U.S. and educational trusts in Britain

However, neo-liberal initiatives focused on privatization and deregulation are only half the picture here. The economic performance of Britain and the United States since 1980 owes just as much to the ways in which their governments have managed the demand side of the economy. In contrast to the export-led models of many corporatist political economies, both countries have long operated growth models in which domestic demand plays a central role, and this did not change in the neo-liberal era.

In Britain, the 'end of the Keynesian era' had barely been proclaimed when the monetarist economics that succeeded it proved unworkable because the money supply is a slippery target (Skidelsky 1978). Despite the misgivings of Prime Minister Thatcher, the Treasury then targeted policy on the exchange rate (Riddell 1991). For the most part, policymakers ignored the purist contentions that monetary policy had no lasting real effects and fiscal policy little influence over the fluctuations of the business cycle. The global enthusiasm for independent central banks, which inspired a 1997 decision to let the Bank of England set interest rates and established a more independent Monetary Policy Committee, did not prevent the Bank from operating an active monetary policy sensitive to the level of economic activity as well as inflation. At the same time, the American Federal Reserve Bank continued to target unemployment as well as inflation (Woolley 1986). In short, most liberal states continued to operate policies built on a pragmatic Keynesianism that soon found reflection in 'new Keynesian’ economic doctrines, although inflation was given higher priority and monetary instruments seen as more effective than fiscal ones (Carlin and Soskice 2005). 
However, new elements were added to the demand-led growth models of these countries in the 1980s. During the 1950s and 1960s, domestic demand was fueled largely by the productivity gains available from industrial production, translated into consumption via the wage gains made possible by regularized collective bargaining (Boyer 1990). Structural shifts in the economy during this period also inspired a vast expansion in white collar jobs, tied to the growth of the welfare state, public employment and tertiary education (Goldthorpe 1978). These developments brought steady gains in income for most of the population, including the wide swath around the median that can be described as middle class. One indicator for demand-led growth was a savings rate significantly lower than that in many corporatist political economies. By the 1980s, however, the basis for continued growth in domestic demand had changed. Employment in manufacturing declined steadily from the early 1950s and, although servicesector employment rose, in these economies much of it was concentrated in low-paid services that offered few productivity gains from which to fund higher wages (Esping-Andersen 1999).

How then was domestic demand sustained enough, after 1980, to support a demand-led growth strategy? Several developments were important. A revolution in information technology that created entirely new sectors and improved productivity in many others drove some growth in employment, as did an inexorable increase in demand for health care, as new technologies became available, especially in the U.S. whose privatized system of health care made cost contrl difficult. Most notable, however, were a series of measures taken to expand the financial sector and the credit available to households (Rajan 2010; Campbell 2010b). Spurred initially by distortions in the credit markets brought about by high rates of inflation in the 1970s followed by high rates of interest in the 1980s, successive British and American governments deregulated the financial markets (Krippner 2011). The result was a vast expansion in the role that finance 
played in the economy. By 2007, more than a third of the profits in the American economy were being generated in the financial sector, and many industrial firms were drawing an increasing share of their profits from financing operations or portfolio investments rather than manufacturing. Partly as a result, income inequality increased dramatically: more than half the fruits of growth in the American economy after 1980 flowed to people in the top one percent of the income distribution, while real incomes at and below the median stagnated (Hacker and Pierson 2009).

In principle, this stagnation in middle incomes should have damaged domestic demand, but freer flows of credit were used to prop it up. Some of the most important steps centered on the housing market (Schwartz and Seabrook 2009). The Thatcher government sold off about two million units of public housing to create many new homeowners and potential Conservative voters. Successive American governments offered tax deductions for mortgage interest, increased federal mortgage guarantees, promoted mortgage-backed securities that increased the availability of credit, and encouraged banks to offer sub-prime housing loans (Campbell 2010). By 2007, 68 percent of American families owned a home, and the value of those homes seemed to be increasing annually. As a result, families whose incomes were stagnating often increased their spending, under the illusion that their wealth was increasing (Schwartz 2009). The savings rate of American households, which had fluctuated between 8 and 10 percent in the previous three decades, fell steadily in the years after 1980 to less than 2 percent by 2008 .

These years also saw a vast expansion in consumer borrowing in the U.S., notably via credit card debt and automobile loans, facilitated by the easy money policies of the Federal Reserve during the 1990s. As median wages stagnated, many Americans had increasing difficulty making ends meet; by the early 2000s, families on average income were spending a 
higher proportion of their income to purchase necessities than they had had in the early 1970s. And, in the absence of a stronger social safety net, many used their credit cards to cope with adverse life events or the vicissitudes of a fluctuating economy (Warren and Tyagi 2004). In short, in liberal market economies, consumer credit often functions as a substitute for more generous welfare states and, although median incomes more grew slowly in the U.S. and Britain

after 1980, more relaxed financial regulations and liberal monetary policies maintained domestic demand.

In the long run, of course, this formula was unsustainable. As the housing market cooled and holders of sub-prime mortgages defaulted, the bottom fell out of the securitized mortgage market, precipitating a global financial crisis and recession in 2008-09. The United States, Britain and Ireland then faced an extended period of deleveraging destined to depress their rates of economic growth for some years (Reinhard and Rogoff 2009).

\section{National Diversity}

If the United States and Britain are paradigmatic cases, whose deregulatory experiments were widely influential, the trajectory of liberal market economies in this era was far from uniform. In some respects, the Irish case is the most distinctive. Its government took advantage of an impending sense of crisis in 1987 to engage trade unions and employers in a succession of social pacts to moderate the growth of wages, generally offering tax concessions in exchange for wage restraint, as one component of a more general move toward economic planning (Culpepper 2008; Regan 2012). The 1986 initiative to create a new single European market also lent new impetus to Irish attempts to attract foreign investment and, by 2000, four fifths of Irish manufacturing was in the hands of multinationals, while employment rose rapidly in the small firms dominating 
the indigenous economy. As labor moved off the land, the country experienced rapid rates of growth.

However, rapid economic growth, the cheap credit made available when Ireland entered European monetary union, and pro-cyclical fiscal policies soon led to an asset boom (Hardiman 2010). At the same time, lax financial regulation, with roots in cozy relations between bankers, the construction sector and a dominant Fianna Fáíl government, encouraged a large expansion in financial services. When the property boom faltered in 2008, several large banks became insolvent. Under pressure from the European central bank, the government was induced to guarantee, not only bank deposits, but the bonds of the banks, thereby taking on unsustainable levels of debt that forced it into an austerity program in return for European loans; and the draconian conditions associated with those loans led the trade unions to withdraw from social partnership arrangements in 2009.

With something of a tme-lag, Canadian governments also turned toward neo-liberal policies in this era, initially marked by free trade agreements in 1988 and 1994 that opened its markets to more intense competition. Influenced by Québec's traditions of social solidarity, Liberal Governments at the national level resisted pressures to deregulate for some years; but the election of two successive Conservative governments after 1984 saw Canada embrace deregulation and neo-liberal reforms to some social policies that were extended by subsequent Liberal governments (Iacobucci et al. 2006). These social policy reforms were marked by movement from universal to targeted benefits and by cutbacks in unemployment benefits and federal transfers for health and social spending (Mahon 2008). As a result, inequalities in income and health began to rise dramatically during the 1990s, even though the country's socialsafety net remains more robust than its American counterpart. The notable exception to these 
trends is in Québec, where activist governments have been the norm since the Quiet Revolution of the 1960s and an extensive 'social economy' survived the neo-liberal era to deliver significantly lower levels of social inequality (Bouchard 2013).

Canada also experienced an expansion in mortgage and consumer lending in this period that sustained consumer spending. A Conservative government under Brian Mulroney liberalized financial regulation. However, the concentrated Canadian banking sector was easier to supervise than the diffuse American markets; and the Canadians retained stricter capital requirements and tightened supervision of the banking system in response to bank and trust company failures in the 1990s. As a result, Canada escaped the mortgage lending crisis that submerged the American economy in 2008. By March 2009, the American government had spent the equivalent of 6.9 percent of GDP on bank bailouts, and the British 19.8 percent of GDP, while the Canadian government spent nothing (Konzelmann et al. 2010).

\section{The Trajectories of the Liberal State}

The relationship between state and economy is different in liberal and coordinated market economies. To some extent, these differences may derive from the fact that many liberal states elect governments via majoritarian electoral rules and operate within Westminster political systems. As Iversen and Soskice (2006, 2009) observe, these rules give political parties strong incentives to cultivate median voters rather than make appeals specifically directed at business or labor, as many parties elected by proportional representation do. As a result, the governments of liberal states often have weaker relationships with organized labor or capital and, with the notable exception of Ireland, less inclination to engage in sustained negotiations with them (Martin and Swank 2012). The multiple veto points of the fissiparous American political system 
also encourage lobbying on behalf of specific interests rather than peak-level bargains with labor or capital. Partly because the voice of organized labor is weaker there and firms tend to prize their capacities to move resources around, liberal states also offer lower levels of social protection than neo-corporatist states (Esping-Andersen 1990; Estevez-Abe et al. 2001).

Have developments during the neo-liberal era significantly altered the role of the state in the economy or eroded the differences between liberal and neo-corporatist states? In general, the continuities seem more striking than the changes over time, partly because liberal principles have long been built into the practices of liberal states. There has been some erosion in the differences between liberal and neo-corporatist states, but largely because the latter have adopted the practices of the former. Cross-national moves to strengthen the work requirements and meanstesting associated with social programs build, for instance, on longstanding features of liberal welfare states, as do recent efforts to reduce levels of employment protection. But there are still significant differences between these types of states because liberalizing reforms have generally gone much farther in liberal market economies than in coordinated market economies (Hall and Gingerich 2009).

However, some of the developments of the neo-liberal era are have certainly been consequential for liberal states. Organized labor is now much weaker, for instance, than it used to be in the liberal economies (Baccaro and Howell 2011). As a result, the wage bargaining systems of these countries are less likely to translate productivity gains into wage gains, which renders domestic demand more sluggish, making it more difficult for these states to operate demand-led growth strategies. And, as the power of trade unions declines and market incomes become more unequal, more of the burden for redistribution shifts onto the state. At the same time, the levels of resources that liberal states devote to improving the skills of the workforce 
have fallen behind those of many of their neo-corporatist counterparts. As a percentage of GDP, the neo-corporatist states of Europe spend two to three times as much as liberal states on manpower policy; and, while levels of public spending on education have risen across much of Europe, they have fallen in the liberal market economies (see Table 22.4). Liberal states now ask students to pay a large share of the costs of tertiary education, and, as a result, the value of outstanding student loans in the U.S. now exceeds $\$ 1$ trillion (Gingrich and Ansell 2010).

These trends raise legitimate concerns about whether liberal states are well-equipped to cope with the economic challenges they are likely to face in the coming decades. Four problems loom large on the horizon of the developed democracies. First, these states will have to cope with aging populations: fewer workers will be supporting the pensions and rapidly-rising healthcare costs of larger numbers of elderly people. Second, after two decades of funding public programs by borrowing, which has now reached unsustainable levels, governments seeking a return to fiscal balance are going to have to make hard choices about which programs to fund, in a context made where these choices have become more difficult because the expansion of entitlement programs is squeezing the scope for discretionary spending and slow rates of growth are likely to constrain overall levels of spending (Scháfer and Streeck 2013). Third, in a more open global economy, where emerging economies that can deploy low-cost labor and the latest technology pose serious competitive pressure, the liberal market economies will have to export enough to pay for their imports or watch their standards of living decline. Fourth, their best chance of doing so lies in promoting high value-added production, but because that is now knowledge-intensive, it demands a workforce equipped with high levels of flexible skills, firms with serious capacities for innovation, and an economy that devotes high levels of 
resources to research and development and is capable of moving resources into sectors utilizing emerging technologies.

Liberal states face these challenges with a singular mix of advantages and handicaps. Partly because they offer many low-wage, low-skill jobs as well as higher-wage employment based on the general skills that can be acquired through formal education, the liberal market economies can accommodate immigrants. Thus, they have a reasonable chance of expanding their working populations enough to support the elderly. However, coping with an aging population also entails managing healthcare costs, and the institutional capacities of liberal states to do so diverge widely: Britain is at one end of the cost-control spectrum and the U.S. at the other.

In some respects, liberal states are relatively well-positioned to cope with the politics of austerity: their low levels of social spending are easier to sustain than the more generous welfare states of other regimes. But the high levels of indebtedness to which their demand-led growth strategies have given rise make this problem more pressing and the relevant choices more painful. Moreover, the obverse of lower levels of spending has been lower levels of taxation; and one might well ask whether these countries are politically capable of funding the kind of government programs likely to be necessary to support the knowledge-intensive economies, on which their international competitive position likely depends. Effective up-skilling of the workforce may depend on reducing the social inequalities that are now prominent features of such economies, via programs of early childhood development and the like, since family conditions are as important to educational achievement as the quality of schools. But the weaker traditions of social solidarity characteristic of such states leave them vulnerable to a sauve-qui-peut politics that resists taxation or further redistribution. 
To the international struggle for economic success, each of the liberal states brings different assets. Like Australia, Canada has reserves of natural resources that will sustain its exports on rising demand from emerging markets, although the exchange-rate effects are likely to have adverse effects on domestic manufacturing. Ireland's continued success in attracting foreign firms will depend on the pace of growth in a European economy that is deeply challenged by the Euro crisis and on resolving the unsustainable debt it has inherited from the banking sector. However, a significant expansion in tertiary education there offers the prospect that it can cultivate the skills of its workforce enough to become a site for high value-added production rather than assembly.

Like the United States, Britain has a large financial services sector with international reach that will continue to make major contributions to its balance of payments, even though it faces downsizing in the short term. The question is whether Britain and the U.S. can also secure market share in other sectors. The United States enjoys historic advantages in biotechnology, aerospace and information technology, linked to its capacities for radical innovation, but, in other sectors, such as sustainable energy, it has been vulnerable to Asian competition. Moreover, in both countries, the fate of knowledge-intensive industry is in doubt because their systems of secondary education have been unable to confer the high levels of skill in mathematics and science that are now attained by some of their competitors.

These economies have well-established capacities to expand employment in sheltered services and are important providers of internationally-traded services in education, tourism and finance. However, as well paid jobs in manufacturing moved overseas, the middle of their occupational structures has been hollowed out (Autor and Dorn 2009; Antras et al. 2006). As state and local governments reduce spending to recover from the recent debt crisis, well-paid 
middle-class jobs in many other sectors, such as education, healthcare and public employment are also disappearing. Ironically, the United States and Britain seem to be losing their middle classes, just as China acquires one.

What might liberal states do if they want to recover prosperous middle-class positions, to anchor their class structures and exporting capacities? One route would be to revive high valueadded manufacturing. Even though technological advances limit the number of new jobs each plant adds to the economy, that kind of manufacturing also stimulates innovation of the sort that can yield more jobs. However, advanced manufacturing requires a highly-skilled workforce. Liberal market economies lack the institutional capacities to cultivate these skills via apprenticeship schemes that are built on close cooperation between business and labor. But they may be able to cultivate them through formal education that promotes high achievement in secondary education and further training in community colleges and vocational schools. This strategy would require serious investments in secondary and tertiary education. At the same time, advances in high value-added manufacturing, of the sort found, for example, in aerospace, also depend on high levels of spending on research and development, some of which will have to come from the public sector.

Until recently, the liberal market economies were relatively successful at job creation, not only in low-wage services but in a wide range of endeavors based on technological revolutions in IT, biotechnology and finance. Can they generate and sustain a new set of technological revolutions capable of creating jobs and exports in the future and, if so, how? One response to this problem, for which there are many advocates, suggests that liberal states should put their faith in the powers of creative destruction inherent in free markets, hoping that this will give rise 
to new technological revolutions. That is a popular position in the United States whose flexible markets have long been propitious sites for radical innovation.

However, the latent preconditions for that innovation were exceptionally high levels of public spending on research and development, generally in the name of national defense, and an unprecedented expansion of higher education that has now run its course (Golden and Katz 2008). Thus, an alternative position suggests that, if liberal market economies are to continue to prosper, they need to make major new public investments in research and development, in skill formation, infrastructure and emerging technologies. In the era of Sputnik and the inter-state highway system, the governments of liberal states were willing to do so, but such programs were subsequently written out of their ideological blueprints for economic success. Ironically, therefore, the future prosperity of many liberal market economies may depend on whether liberal states can transcend the dictates of neo-liberal ideology and summon up the political will to invest more heavily in their economies than they have in recent decades.

In short, while liberal states have been different from neo-corporatist ones for at least the seven decades since the Second World War and perhaps for far longer than that, their posture vis-à-vis the economy has also fluctuated a good deal over that time. Although various factors may keep liberal states and liberal economies moving along parallel tracks (Iversen and Soskice 2009), the relationship between them has never been fixed or entirely stable over time. Moreover, given the dilemmas facing liberal market economies today, the transformation of the liberal state is probably far from over. 


\section{Acknowledgements}

For comments on a previous draft, I am grateful to the editors and Niamh Hardiman.

\section{References}

Alesina, Alberto and Edward Glaeser. 2004. Fighting Poverty in the US and Europe. New York: Oxford University Press.

Amable, Bruno. 2003. The Diversity of Modern Capitalism. Oxford: Oxford University Press.

Antràs, Pol, Luis Garicano and Esteban Rossi-Hansberg. 2006. “Offshoring in a Knowledge Economy,” Quarterly Journal of Economics.

Autor, David and David Dorn. 2009. "Inequality and Specialization: The Growth of Low-Skill Service Jobs in the United States.

Avgadic, Sabina, Martin Rhodes and Jelle Visser, eds. 2011. Social Pacts in Europe. Oxford: Oxford University Press.

Baccaro, Lucio and Chris Howell. 2011. “A Common Neoliberal Trajectory: The Transformation of Industrial Relations in Advanced Capitalism,” Politics \& Society 39(4): 521-63.

Beer, Samuel H. 1969. British Politics in the Collectivist Age. New York: Norton.

Beer, Samuel H. 1974. Modern Political Development. New York: Random House.

Blank, Stephen. 1978. "Britain: The Politics of Foreign Economic Policy: The Domestic Economy and the Problem of Pluralistic Stagnation” in Peter Katzenstein, ed. Between Power and Plenty. Madison: University of Wisconsin Press, pp. 89-138.

Blyth, Mark M.. 2002. Great Transformations: Economic Ideas and Political Change in the Twentieth Century. New York: Cambridge University Press.

Bouchard, Gérard. 2013. “Neo-Liberalism In Québec:The Response of a Small Nation under Pressure.” In. Peter A. and Michèle Lamont, eds. Social Resilience in the Neoliberal Era. New York: Cambridge University Press: pp. 267-92.

Boyer, Robert. 1990. The Regulation School: A Critical Introduction. New York: Columbia University Press.

Boyer, Robert. 2002. Ed. Regulation Theory: The State of the Art. London: Routledge.

Brittan, Samuel. 1970. Steering the Economy. Harmondsworth: Penguin.

Campbell, John. L. 2010a. “Neoliberalism’s Penal and Debtor States,” Theoretical Criminology 14(1): 59-73. 
Campbell, John L. 2010b. "Neoliberalism in Crisis: Regulatory Roots of the U.S. Financial Meltdown." Research in the Sociology of Organizations 30B:65-101.

Carlin, Wendy and David Soskice. 2005. Macroeconomics: Imperfections, Institutions and Policy. Oxford: Oxford University Press.

Clement, Wallace and Glen Williams. The New Canadian Political Economy. Montreal: McGill-Queens University Press. 1989.

Crozier, Michel, Samuel P. Huntington and Joji Watanuki. 1974. The Crisis of Democracies. New York: New York University Press.

Crystal, Alec. 1979. Controversies in British Macroeconomics. London: Philip Alan.

Culpepper, Pepper. 2008. "The Politics of Common Knowledge: Ideas and Institutional Change in Wage Bargaining,” International Organization 62 (Winter): 1-33.

Cuthbertson, Keith. 1979. Macroeconomic Policy: The New Cambridge, Keynesian and Monetarist Controversies. London: Macmillan.

Dyson, Kenneth. 1980. The State Tradition in Western Europe. Oxford: Oxford University Press.

Esping-Andersen, Gosta, 1990: Three Worlds of Welfare Capitalism. Princeton: Princeton University Press.

Esping-Andersen, Gosta. 1999. Social Foundations of Post-Industrial Economies. Oxford: Oxford University Press.

Estevez-Abe, Margarita, Torben Iversen and David Soskice. 2001. "Social Protection and the Formation of Skills: A Reinterpretation of the Welfare State," in Peter A. Hall and David Soskice, eds. Varieties of Capitalism: The Institutional Foundations of Comparative Advantage. Oxford: Oxford University Press: 145-83.

Evans, Peter. 1995. Embedded Autonomy: States and Industrial Transformation. Princeton: Princeton University Press.

Ferguson, Niall, Charles S. Maier, Erez Manela and Daniel J. Sargent, eds. 2010. The Shock of the Global: The 1970s in Perspective. Cambridge, Ma.: Harvard University Press.

Gamble, Andrew. 1994. The Free Economy and the Strong State: The Politics of Thatcherism. $2^{\text {nd }}$ ed. Houndsmills: Palgrave Macmillan.

Gingrich, Jane and Ben Ansell. 2010. “A Tale of Two Trilemmas: Varieties of Higher Education and the Service Economy.” Manuscript. University of Minnesota.

Glyn, Andrew. 2006. Capitalism Unleashed. Oxford: Oxford University Press.

Goldin, Claudia and Lawrence F. Katz. 2008. The Race Between Education and Technology. Cambridge: MA: Harvard University Press. 
Goldthorpe, John H. ed.. 1984. Order and Conflict in Contemporary Capitalism. New York: Oxford University Press.

Hacker, Jacob. 2004. "Privatizing Risk Without Privatizing the Welfare State: The Hidden Politics of Social Policy Retrenchment in the United States,” American Political Science Review 98(2): 243-60

Hacker, Jacob and Paul Pierson. 2009. Winner-Take-All Politics. New York: Simon and Schuster.

Hall, Peter A. 1986. Governing the Economy. Oxford: Polity Press.

Hall, Peter A.. ed. 1989. The Political Power of Economic Ideas. Princeton: Princeton University Press.

Hall, Peter A. 1993. "Policy Paradigms, Social Learning and the State: The Case of Economic PolicyMaking in Britain,” Comparative Politics (April): 275-96.

Hall, Peter A.and Michèle Lamont, eds. 2013. Social Resilience in the Neoliberal Era. New York: Cambridge University Press.

Hall, Peter A. and Daniel Gingerich. 2009. "Varieties of Capitalism and Institutional Complementarities in the Political Economy: An Empirical Analysis,” British Journal of Political Science 39: 449-482.

Hall, Peter A. and David Soskice. 2001. eds., Varieties of Capitalism: The Institutional Foundations of Comparative Advantage. Oxford: Oxford University Press.

Hansen, Berndt. 1968. Fiscal Policy in Seven Countries 1955-1965. Paris: OECD.

Hardiman, Niamh. 1988. Pay, Politics and Economic Performance in the Republic of Ireland. Oxford: Clarendon Press.

Hardiman, Niamh. 2010. “Bringing Domestic Institutions Back into an Understanding of Ireland’s Economic Crisis,” Irish Studies in International Affairs 21: xx

Hardiman, Niamh. ed. 2012. Irish Governance in Crisis. Manchester: Manchester University Press.

Hibbs, Douglas. Jr. 1977. “Political Parties and Macroeconomic Policy,” American Political Science Review 71, 4: 1467-87.

Howell, Chris. 2002. Trade Unions and the State: The Construction of Industrial Relations Institutions in Britain 1890-2000. Princeton: Princeton University Press.

Howlett, Michael, Alex Netherton and M. Ramesh. 1999. Political Economy of Canada. New York: Oxford University Press.

Huber, Evelyne and John D. Stephens. 2001. Development and Crisis of the Welfare State. Chicago: University of Chicago Press.

Iacobucci, Edward, Michael Trebilcock and Ralph Winter. 2006. “The Political Economy of Deregulation in Canada.” Working Paper. Phelps Centre for the Study of Government and Business, University of British Columbia. 
Iversen, Torben. 2006. "Class Politics is Dead! Long Live Class Politics! A Political Economy Perspective on the New Partisan Politics,” APSA-CP Newsletter 17(20): 1-6.

Iversen, Torben and John D. Stephens. 2007. "Partisan Politics, the Welfare State and Three Worlds of Human Capital Formation,” Comparative Political Studies: 1-38

Iversen, Torben and David Soskice 2006. "Electoral Systems and the Politics of Coalitions: Why Some Democracies Redistribute More than Others,” American Political Science Review 100: 165-81.

Iversen, Torben and David Soskice. 2009. "Distribution and Redistribution: The Shadow of the Nineteenth Century,” World Politics 61: 3 (July).

Jabko, Nicolas. 2006. Playing the Market: A Political Strategy for Uniting Europe 1985-2005. Ithaca: Cornel University Press.

Jenson, Jane. 1989. “Different but not 'Exceptional”: Canada’s Permeable Fordism,” Canadian Review of Anthropology and Sociology 26, 1: 69-

Johnson, Chalmers. 1982. MITI and the Japanese Miracle. Stanford: Stanford University Press.

Katzenstein, Peter. 1985. Small States in World Markets. Ithaca: Cornell University Press.

Kitschelt, Herbert, Peter Lange, Gary Marks and John Stephens. Eds. 1999. Continuity and Change in Contemporary Capitalism. New York: Cambridge University Press.

Konzelmann, Suzanne, Marc Fovargue-Davies and Gerhard Schnyder. 2010. "Varieties of Liberalism: Anglo-Saxon Capitalism in Crisis?” Centre for Business Research, University of Cambridge, Working Paper No. 403.

Kreile, Michael. 1978. "West Germany: The Dynamics of Expansion,” in Katzenstein, ed. Between Power and Plenty. Madison: University of Wisconsin Press, pp. 191-224.

Krieger, Joel. 1986. Reagan, Thatcher and the Politics of Decline. New York: Oxford University Press.

Krippner, Greta R. 2011. Capitalizing on Crisis. Cambridge, MA: Harvard University Press.

Leruez, Jacques. 1975. Economic Planning and Politics in Britain. London: Martin Robertson.

Levy, Jonah, ed. 2006. The State after Statism. Cambridge: Harvard University Press.

Mahon, Rianne. 2008. "Varieties of Liberalism: Canadian Social Policy from the 'Golden Age' to the Present,” Social Policy and Administration 42(4): 342-61.

Martin, Andrew. 1979. "The Dynamics of Change in a Keynesian Political Economy: The Swedish Case and its Implications.” In Colin Crouch, ed., State and Economy in Contemporary Capitalism. London: Croom Helm.

Martin, Cathie Jo and Duane Swank. 2012. The Political Construction of Business Interests. New York: Cambridge University Press. 
McArthur, John D. and Bruce Scott. 1966. Industrial Planning in France Cambridge: Harvarfd Business School.

Peter Miller and Nikolas Rose. 1990. “Governing Economic Life,” Economy and Society. 19(1): 1-31.

Moran, Michael. 2003. The British Regulatory State. Oxford: Oxford University Press.

Myles, John. 1998. "How to Design a Liberal Welfare State: A Comparison of Canada and the United States,” Social Policy and Administration 32(4): 341-64.

Nolan, Brian, Philip J. O’Connell, and Christopher T. Whelan, eds. 2000. Bust to Boom? The Irish Experience of Growth and Inquality. Dublin: xx

Pemberton, Hugh. 2004. Policy Learning and British Governance in the 1960s. Houndsmills: Palgrave Macmillan.

Pierson, Paul. Ed. 2001. The New Politics of the Welfare State. New York: Oxford University Press.

Pizzorno, Alessandro. 1978. "Political Exchange and Collective Identity in Industrial Conflict.” In Colin Crouch and Alessandro Pizzorno, eds., The Resurgence of Class Conflict in Western Europe since 1968.

London: Macmillan.

Polanyi, Karl. 1944. The Great Transformation. Boston: Beacon Press.

Prasad, Monica. 2006. The Politics of Free Markets: The Rise of Neoliberal Economic Policies in Britain, France, Germany and the United States. Chicago: University of Chicago Press.

Przeworski, Adam and Michael Wallerstein. 1982. "The Structure of Class Conflict in Democratic Capitalist Societies,” American Political Science Review 76: 215-38.

Rajan, Ragurham. 2010. Fault Lines: How Hidden Fractures Still Threaten the World Economy. Princeton: Princeton University Press.

Regan, Aidan. 2012. The Rise and Fall of Irish Social Partnership. Ph.D. Thesis for University College, Dublin.

Regini, Marino 1984. "The Conditions for Political Exchange: How Concertation Emerged and Collapsed in Britain and Italy,” in John A. Goldhorpe, ed. Order and Conflict in Contemporary Capitalism. New York: Oxford University Press, 124-42.

Reinhard, Carmen and Kenneth Rogoff. 2009. This Time is Different. Princeton: Princeton University Press.

Rhodes, R.A.W. (1994), 'The Hollowing Out of the State: the Changing Nature of the Public Service in Britain', Political Quarterly, 65 (2), 138-51.

Riddell, Peter. 1991. The Thatcher Era and its Legacy. Oxford: Basil Blackwell. 
Sandbrook, Dominic. 2010. State of Emergency: The Way We Were. Britain. 1970-1974. London: Allen Lane.

Schäfer, Armin and Wolfgang Streeck. eds. 2013. Politics in an Age of Austerity. Cambridge: Polity.

Schmitter, Philippe and Gerhard Lehmbruch. eds. 1979. Trends Toward Corporatist Intermediation.

Beverly Hills: Sage.

Schwartz, Herman. 2009. Subprme Nation. Ithaca: Cornell University Press.

Schwartz, Herman and Leonard Seabrook eds. 2009. The Politics of Housing Booms and Busts.

Basingstoke: Palgrave Macmillan.

Shonfield, Andrew. 1969. Modern Capitalism. Oxford: Oxford University Press.

Skidelsky, Robert. 1978. ed. The End of the Keynesian Era. London: Holmes and Meier.

Steensland, Brian. 2006. "Cultural Categories and the American Welfare State: The Case of Guaranteed Income Policy,” American Journal of Sociology 111, 5 (March): 1273-1326.

Surrey, Michael. 1982. "United Kingdom” in Andrea Boltho, ed., The European Economy: Growth and Crisis. Oxford: Oxford University Press, pp. 528-53.

Thelen, Kathleen. 2004. The Evolution of Institutions. New York: Cambridge University Press.

Trumbull, Gunnar. 2012. Consumer Credit in Postwar America and France. New York: Cambridge University Press.

Tyagi, Amelia W. and Elizabeth Warren. 2003. The Two-Income Trap: Why Middle Class Mothers and Fathers Are Going Broke. New York: Basic.

Vogel, Steven. 1998. Freer Markets, More Rules: Regulatory Reform in Advanced Industrial Countries. Ithaca: Cornell University Press.

Wacquant, Loic. 2009. Punishing the Poor: The Neoliberal Government of Social Insecurity. Durham, NC: Duke University Press.

Woolley, John. 1986. Monetary Politics: The Federal Reserve and the Politics of Monetary Policy. New York: Cambridge University Press.

Zysman, John. 1983. Governments, Markets and Growth: Financial Systems and the Politics of Industrial Change. Ithaca: Cornell University Press. 